\title{
Fresh vegetable and fruit consumption and carotid atherosclerosis in high-cardiovascular- -risk population: a cross-sectional study in Jiangsu, China
}

\author{
Consumo de frutas e verduras frescas e \\ aterosclerose carotídea em uma população \\ de alto risco cardiovascular: um estudo \\ transversal em Jiangsu, China
}

\author{
Consumo de verduras frescas y fruta y la \\ aterosclerosis carotídea en una población \\ con alto riesgo cardiovascular: un estudio \\ trasversal en Jiangsu, China
}

\author{
Fangyu Zhu 1,2 \\ Yu Qin 3 \\ Yuan Bi 4 \\ Jian Su 3 \\ Lan $\mathrm{Cui} 3$ \\ Pengfei Luo 3 \\ Wencong $\mathrm{Du} 3$ \\ Weigang Miao 3 \\ Jinsong Wang 1,2 \\ Jinyi Zhou 3
}

\begin{abstract}
This study aimed to investigate the association of vegetable and fruit consumption with carotid plaque (CP) and carotid intima-media thickness (CIMT), two predictors of carotid atherosclerosis, within urban and rural adults at high risk of developing cardiovascular diseases (CVDs) in regional China. A total of 11,392 adults at high CVD risk were identified from general population of 71,511 in this cross-sectional study, conducted between November of 2015 and May of 2016 in the Jiangsu Province. Among these 11,392 high risk participants, CP prevalence was $36.7 \%$. The independent variables, vegetable and fruit intake frequency, were assessed by a food frequency questionnaire. The outcome variables, CIMT and CP, were measured by ultrasound examination. The ANCOVA analysis showed no association between CIMT values and vegetable and fruit intake frequencies. Multivariate logistic regression models were introduced to examine the association between vegetable and fruit intake and CP. After adjustment for potential confounders, the odds ratios (ORs) for participants who occasionally and daily consumed vegetable to experience any CP were 0.67 (95\%CI: 0.58-0.78) and 0.70 (95\%CI: 0.62-0.79), respectively, compared with those rarely consumed vegetable. While the adjusted ORs were 0.77 (95\% CI: 0.64-0.92) and 0.80 (95\%CI: 0.68-0.94), separately, for occasional and daily vegetable consumers to develop single CP relative to their counterparts who rarely consumed any vegetables. However, no significant association between fruit consumption and CP was observed. Among the Chinese population at high CVD risk, consumption of fresh vegetables was negatively associated with the risk of developing carotid plaque.
\end{abstract}

Cardiovascular Diseases; Atherosclerosis; Carotid Intima-Media Thickness; Carotid Artery Plaque

\author{
Correspondence \\ J. Zhou \\ Department of Non-communicable Chronic Disease Control, \\ Jiangsu Provincial Center for Disease Control and Prevention. \\ 172 Jiangsu Rd., Gulou, Nanjing / Jiangsu Province - 210013, \\ China. \\ zhoujinyi74@sina.com \\ ${ }^{1}$ Clinical Epidemiology Research Center, Yangzhou University \\ Medical College, Yangzhou, China. \\ 2 Affiliated Hospital to Yangzhou University, Yangzhou, China. \\ 3 Department of Non-communicable Chronic Disease Control, \\ Jiangsu Provincial Center for Disease Control and Prevention, \\ Nanjing, China. \\ ${ }_{4}$ School of Public Health, Southeast University, Nanjing, China.
}




\section{Background}

Cardiovascular diseases (CVDs), such as ischemic heart disease and stroke, is a leading cause of death and disease burden worldwide, including in China 1,2. It accounts for more than $80 \%$ of the total disease burden in low- and middle-income countries 3 , expected to increase in the next decades 4,5 . Cardiovascular events are the end-stage performance of atherosclerosis, and sub-clinical atherosclerosis can persist for a long time before these events occur 6 . Carotid intima-media thickness (CIMT) and carotid plaque (CP), measured with ultrasound imaging, are noninvasive measurements of carotid atherosclerosis, which can be usually used to predict carotid atherosclerosis and subsequently the risk of sub-clinical CVDs and subsequent cardiovascular events 7 . Therefore, understanding modifiable risk factors of CIMT and CP is helpful for population-based tailored interventions against cardiovascular events.

Fresh vegetables and fruits are important sources of antioxidant vitamins, minerals, fibers, and other nutrients 8,9. The literature recommends people to consume sufficient amounts of fresh vegetables and fruits as a healthy dietary pattern 10. Regarding the association of vegetable and fruit consumption with the risk of CVD, previous studies are inconsistent so far 11,12. Moreover, the relationship between vegetable/fruit intake and carotid atherosclerosis was less studied for people at high CVD risk. Furthermore, most of the studies were from Western societies rather than developing countries, where both disease patterns and lifestyle-related risk factors were substantially different from that in developed communities 3,13. Therefore, we conducted this study seeking to examine the association of fresh vegetable and fruit consumption with CP and CIMT among high CVD risk population in regional China.

\section{Methods}

\section{Participants and study design}

As a part of the China PEACE Million Persons Project (MPP) 2015-2016, this study (MPP-Jiangsu) was a cross-sectional survey conducted during the period of November, 2015 and May, 2016 in the Jiangsu province, China. The study design and participants have been detailed elsewhere 14. Briefly, the eligible participants (adults at high CVD risk), were local registered residents aged 35-75 that had any of the following CVD risk factors: (i) being diagnosed with myocardial infarction, ischemic or hemorrhagic stroke, percutaneous coronary intervention, or coronary artery bypass; (ii) systolic blood pressure (SBP) $\geq 160 \mathrm{mmHg}$ or diastolic blood pressure (DBP) $\geq 100 \mathrm{mmHg}$; (iii) LDL-C $\geq$ $4.14 \mathrm{mmol} / \mathrm{L}$ or HDL-C $<0.78 \mathrm{mmol} / \mathrm{L}$; (iv) the risk score of CVD is $\geq 20 \%$, based on the World Health Organization (WHO) risk assessment prediction chart 15. For the MPP-Jiangsu project, the sample size was determined based on: (i) estimated proportion of people at high CVD risk among the general population and CP prevalence among the high-risk population in our pilot study; (ii) a stratified multi-stage sampling method; (iii) expected response rate (80\%). Thus, it was estimated that approximately 70,000 people among the general population and 11,000 participants at high CVD risk could guarantee the statistical power in the study. With consideration of participants' representativeness and field work convenience, we expected to recruit 280-300 participants based on the proportion of sample/overall population to each age-group from each village/neighborhood, the smallest sampling unit in our study.

Based on the sampling approach, we selected 6 from 13 cities in the Jiangsu province; next, we randomly chose one district/county from each selected city; then, 5-6 administrative streets/towns were randomly selected from each district/county; next, 7-8 villages/neighborhoods were randomly chosen from each street/town, thus having 252 villages/neighborhoods selected in total; and finally, eligible participants within each selected village/neighborhood were asked to take part in the study with a convenience sampling method, resulting in 71,511 eligible participants recruited. Among these 71,511 participants, 11,392 were identified as subjects at high CVD risk and received ultrasound examination and detailed questionnaire survey. 
The MPP project was reviewed and approved by the ethics committee at the China National Center for Cardiovascular Disease, and written informed consent was obtained from each participant before the study.

\section{Data collection}

Data were gathered, via interviewer-administered survey, on participants' sociodemographic characteristics, lifestyle and behaviors, medication, and dietary intake via face-to-face interview; physical measurements, laboratory tests and ultrasound examination were implemented by trained personnel. Sociodemographic information included age, gender, residence, household income and educational level. Lifestyle and behaviors included smoking, drinking and dietary intake. Medication was defined as that participants took medication for CVDs by physician's prescription. Physical measurements referred to body weight and height assessment, tests for blood pressure and glucose level as well as lipid profile. Ultrasound examination was conducted to identify CP and CIMT for each high-risk participant.

\section{Study variables}

\section{- Outcome variables: CP and CIMT}

CP, a predictor of carotid atherosclerosis, was used as our study variable. Carotid artery ultrasound examination was performed with a $5-12 \mathrm{MHz}$ linear array transducer ultrasound system. Participants at high CVD risk were examined in a supine position. Registered ultrasound physicians scanned from common carotid artery (CCA) to carotid bifurcation, internal carotid artery, and external carotid artery in transverse and longitudinal sections to check for CIMT and presence of CP. Presence of CP was defined as a region with CIMT $\geq 1.5 \mathrm{~mm}$, protruding into the arterial lumen, or an endoluminal protrusion of more than $0.5 \mathrm{~mm}$ or $50 \%$ of the surrounding intima-media thickness value 16 . In the analysis, participants were classified as: "having CP" or "having no CP". Those with occurrence of CP were further categorized into: "having single CP" or "having multiple CPs", according to the number of plaques.

CIMT, the other predictor of carotid atherosclerosis in this study, was also used as the outcome variable, which was determined by measuring distance between the intimal-luminal and medialadventitial interfaces of the vascular wall 17 . Three CIMT measurements were recorded on the near, medium, and far wall of the left and right CCA 18,19. The mean value of CIMT readings for each participant was used as continuous variable in our analysis.

\section{- Independent variables: fruit and vegetable intake}

Consumption of vegetables and fruits was our independent measurement (categorical variable). Information on dietary intake was collected with a food frequency questionnaire (FFQ) 20. Participants were asked to report their food intake within typical days in the past year. The original answer to food intake frequency included: "never or rarely", "1-3 days/month", "1-3 days/week", "4-6 days/ week", or "daily". In the analysis, participants were classified into three categories: (i) Rarely consumed ("never or rarely" or "1-3 days/month"); (ii) Occasionally consumed ("1-3 days/week" or "4-6 days/ week”); or (iii) Daily consumed ("daily”).

\section{- Covariates}

The following classical potential confounders were adjusted for in the multivariate analysis in this study: age (continuous variable), gender (men or women), annual household income in Chinese Yuans - CNY ( $<10,000,10,000-50,000, \geq 50,000)$, educational attainment in years (6, 7-12, or 13+, based on schooling years completed), smoking status ("yes" or "no"), drinking status ("yes" or "no"), body mass index - BMI (calculated as weight divided by square of height $\left(\mathrm{kg} / \mathrm{m}^{2}\right)$ ), hypertension (defined 
as $\mathrm{SBP} \geq 140 \mathrm{mmHg}$ or $\mathrm{DBP} \geq 90 \mathrm{mmHg}$, or self-reported use of antihypertensive drugs in the past two weeks 21 , and classified as "yes" or "no"), hyperglycemia (defined as FPG $\geq 7.0 \mathrm{mmol} / \mathrm{L}$, or self-reported use of antidiabetic medications in the past two weeks 22, and categorized as "yes" or "no"), dyslipidemia (defined as TC $\geq 6.2 \mathrm{mmol} / \mathrm{L}$, or TG $\geq 2.3 \mathrm{mmol} / \mathrm{L}$, or $\mathrm{HDL}-\mathrm{C}<1.0 \mathrm{mmol} / \mathrm{L}$, or $\mathrm{LDL}-\mathrm{C} \geq 4.1 \mathrm{mmol} / \mathrm{L}$, or self-reported use of lipid-lowering drugs over the past two weeks 23 , and classified as "yes" or "no").

Blood pressure was measured using electronic blood pressure monitor (Omron HEM-1300 Omron Corp.; https://www.omron.com/global/en/) for two times on right upper arm in a seated position after 5 minutes of rest. Fasting blood glucose (FPG) and lipid profile were assessed by rapid blood glucose (BeneCheck BK6-20MD - General Life Biotechnology Co.; http://www.glbiotech.com. tw) and lipid (CardioChek PA - PTS Diagnostics; https://ptsdiagnostics.com/) analyzer, respectively.

\section{Statistical analysis}

Continuous variables were expressed as means with standard deviations (SD), and categorical data were presented as percentages. General characteristics were compared across number of CPs by using Pearson's test and one-way analysis of variance (ANOVA). CIMT values were compared across different dietary intake frequencies with adjustment for covariates via analysis of covariance (ANCOVA). Logistic regression models were introduced in order to compute odds ratio (OR) and 95\% confidence interval (95\%CI) to assess the association of vegetable and fruit consumption with CP, and to evaluate association between food intake frequency and single CP. All covariates were controlled for in multivariable models. All data analyses were performed on IBM SPSS Statistics 23.0 (https://www. ibm.com).

\section{Results}

Totally, 71,511 residents aged 35-75 years old were initially interviewed for assessing the risk of CVDs. There was no significant difference in age, gender, or urban/rural residence between these 71,511 participants and the overall standard population of the Jiangsu Province. Among these initially interviewed participants, 11,392 were identified as subjects at high CVD risk and subsequently included in the analysis as our study participants. The selected characteristics of the study participants are presented in Table 1. Among the 11,392 study subjects, the mean (SD) age was 59.4 (8.9) years; $42.3 \%$ were men; $57 \%$ had educational attainment of 6 years; $17.2 \%$ reported annual household income less than CNY 10,000; 22.3\% were current smokers and 29.5\% were alcohol drinkers; and the mean (SD) BMI was 26.4 (3.4).

The prevalence of CP was $36.7 \%(4,186 / 11,392)$ among our study participants who were at high CVD risk. There were significant differences $(\mathrm{p}<0.001)$ between subjects with and without CP in gender, age, residence, educational level, socioeconomic status, smoking and drinking status, BMI, and vegetable and fruit intake. The overall prevalence of CP was $41.9 \%$ among men, with $25 \%$ for single CP prevalence and $16.9 \%$ for multi-CP prevalence. For women, the overall CP prevalence was $32.9 \%$, with $22 \%$ and $10.9 \%$ for single and multi-CP prevalence, respectively. Participants with more CPs tended to be older. The mean (SD) age for subjects without CP, with single CP and multiple CPs were 57.3 (8.9), 61.9 (7.8), and 65.0 (6.8), respectively. Overall, 68.6\% of participants reported daily consumption of fresh vegetables (daily consumers) and $9.6 \%$ were rare consumers. The proportion of rare consumers of fresh vegetables was $14.9 \%, 9.9 \%$ and $8.4 \%$ among participants with multiple, single and no CPs, respectively. With respect to fresh fruit consumption, $18.6 \%$ of the participants were daily consumers and $34.4 \%$ were rare consumers.

Table 2 shows mean CIMT among participants by dietary intake frequencies. There were no significant differences in CIMT values across fresh vegetable and fruit intake frequencies, with or without adjustment for potential confounders ( $\mathrm{p}>0.05$ ).

Table 3 presents the association of vegetable and fruit consumption with CP among study participants. Compared to those who rarely consumed vegetables, individuals who occasionally $(\mathrm{OR}=$ 0.67; 95\%CI: 0.58-0.78) and daily (OR = 0.70; 95\%CI: 0.62-0.79) consumed vegetables were significantly less likely to experience CP. After adjustment for potential confounders, such an association 
Table 1

Selected characteristics among the 11,392 study population at high cardiovascular diseases (CVD) risk.

\begin{tabular}{|c|c|c|c|c|c|}
\hline \multirow[t]{3}{*}{ Characteristics } & \multirow{3}{*}{$\begin{array}{l}\text { Participants } \\
\qquad \%(n)\end{array}$} & \multirow{3}{*}{$\begin{array}{l}\text { Subjects without CP } \\
\qquad \%(n)\end{array}$} & \multirow{2}{*}{\multicolumn{2}{|c|}{$\begin{array}{c}\text { Subjects with CP(s) } \\
\qquad \%(n)\end{array}$}} & \multirow[t]{3}{*}{ p-value } \\
\hline & & & & & \\
\hline & & & Single CP & Multiple CPs & \\
\hline Overall [n] & 11,392 & 7,206 & 2,653 & 1,533 & \\
\hline Gender & & & & & $<0.001$ \\
\hline Men & $42.3(4,821)$ & $38.9(2,800)$ & $45.3(1,203)$ & $53.4(818)$ & \\
\hline Women & $57.7(6,571)$ & $61.1(4,406)$ & $54.7(1,450)$ & $46.6(715)$ & \\
\hline Age (years) [mean \pm SD] & $59.4 \pm 8.9$ & $57.3 \pm 8.9$ & $61.9 \pm 7.8$ & $65.0 \pm 6.8$ & $<0.001$ \\
\hline Residence & & & & & $<0.001$ \\
\hline Urban & $44.2(5,039)$ & $37.0(2,663)$ & $50.4(1,336)$ & $20.6(1,040)$ & \\
\hline Rural & $55.8(6,353)$ & $63.0(4,543)$ & $49.6(1,317)$ & $32.2(493)$ & \\
\hline Educational level (years) & & & & & $<0.001$ \\
\hline 6 & $57.0(6,491)$ & $53.5(3,853)$ & $63.9(1,695)$ & $61.5(943)$ & \\
\hline $7-12$ & $37.5(4,277)$ & $40.4(2,908)$ & $31.7(824)$ & $34.4(527)$ & \\
\hline $13+$ & $5.5(624)$ & $6.2(445)$ & $4.4(116)$ & $4.1(63)$ & \\
\hline Annual household income (CNY/year) & & & & & $<0.001$ \\
\hline$<10,000$ & $17.2(1,958)$ & $15.1(1,090)$ & $18.9(501)$ & $24.0(367)$ & \\
\hline $10,000-50,000$ & $54.5(6,205)$ & $53.6(3,860)$ & $56.0(1,486)$ & $56.0(859)$ & \\
\hline$\geq 50,000$ & $28.3(3,229)$ & $31.3(2,256)$ & $25.1(666)$ & $20.0(307)$ & \\
\hline Current cigarette smoking & $22.3(2,535)$ & $19.7(1,423)$ & $24.5(651)$ & $30.1(461)$ & $<0.001$ \\
\hline Alcohol drinking & $29.5(3,358)$ & $27.2(1,961)$ & $32.2(854)$ & $35.4(543)$ & $<0.001$ \\
\hline $\mathrm{BMI}\left(\mathrm{kg} / \mathrm{m}^{2}\right)[$ mean $\pm \mathrm{SD}]$ & $26.4 \pm 3.4$ & $26.5 \pm 3.4$ & $26.2 \pm 3.3$ & $26.2 \pm 3.5$ & $<0.001$ \\
\hline Hypertension & $90.4(10,301)$ & $88.8(6,397)$ & $92.0(2,442)$ & $95.4(1,462)$ & $<0.001$ \\
\hline Hyperglycemia & $25.9(2,947)$ & $22.9(1,649)$ & $28.8(764)$ & $34.9(534)$ & $<0.001$ \\
\hline Dyslipidemia & $54.8(6,243)$ & $54.9(3,953)$ & $54.8(1,455)$ & $54.5(835)$ & 0.961 \\
\hline Fresh vegetables & & & & & $<0.001$ \\
\hline Rarely consumed & $9.6(1,098)$ & $8.4(607)$ & $9.9(263)$ & $14.9(228)$ & \\
\hline Occasionally consumed & $21.8(2,484)$ & $22.3(1,608)$ & $21.4(568)$ & $20.1(308)$ & \\
\hline Daily consumed & $68.6(7,810)$ & $69.3(4,991)$ & $68.7(1,822)$ & $65.0(997)$ & \\
\hline Fresh fruits & & & & & $<0.001$ \\
\hline Rarely consumed & $34.4(3,915)$ & $32.2(2,317)$ & $36.1(958)$ & $41.7(640)$ & \\
\hline Occasionally consumed & $47.0(5,357)$ & $48.4(3,489)$ & $46.3(1,229)$ & 41.7 (639) & \\
\hline Daily consumed & $18.6(2,120)$ & $19.4(1,400)$ & $17.6(466)$ & $16.6(254)$ & \\
\hline
\end{tabular}

BMI: body mass index; CP: carotid plaque.

still remained significant. However, the association between fruit intake and CP attenuated to be non-significant after control for covariates. The OR was 0.87 (95\%CI: 0.79-0.95) for subjects with occasional consumption of fruit to experience CP relative to their counterparts who rarely consumed fruit. However, for those daily fruit consumers relative to rare consumers, the OR was 0.95 (95\%CI: 0.84-1.07), which was not significant.

It is a reasonable development process that people may experience single $\mathrm{CP}$ and then multiple CPs, thus it was interestingly for us to have a look at the association of vegetable and fruit consumption with the risk of developing single CP in this study (Table 4). Compared to rare vegetable consumers, the adjusted OR for occasional fresh vegetable consumers to develop single CP was 0.77 (95\%CI: 0.64-0.92) and 0.80 (95\%CI: 0.68-0.94) for daily vegetable consumers. However, after adjustment for potential confounders, the association between fruit intake and the risk of developing single CP was non-significant for participants who either occasionally $(\mathrm{OR}=0.93$; 95\%CI: 0.84-1.03) or daily $(\mathrm{OR}=0.98$; 95\%CI: $0.86-1.12)$ consumed fruit relative to those who rarely consumed fruit. 
Table 2

Comparison of carotid intima-media thickness (CIMT) values between participants by dietary intake frequencies.

\begin{tabular}{|c|c|c|c|c|}
\hline & $\begin{array}{c}\text { CIMT } \\
\text { mean } \pm \text { SD }\end{array}$ & p-value * & $\begin{array}{c}\text { Adjusted CIMT } \\
\text { mean } \pm \text { SD }\end{array}$ & p-value ** \\
\hline Fresh vegetables & & 0.167 & & 0.057 \\
\hline Rarely consumed & $0.73 \pm 0.20$ & & $0.73 \pm 0.01$ & \\
\hline Occasionally consumed & $0.75 \pm 0.27$ & & $0.75 \pm 0.01$ & \\
\hline Daily consumed & $0.75 \pm 0.25$ & & $0.75 \pm 0.00$ & \\
\hline Fresh fruits & & 0.625 & & 0.239 \\
\hline Rarely consumed & $0.75 \pm 0.26$ & & $0.74 \pm 0.00$ & \\
\hline Occasionally consumed & $0.75 \pm 0.23$ & & $0.75 \pm 0.00$ & \\
\hline Daily consumed & $0.74 \pm 0.31$ & & $0.75 \pm 0.01$ & \\
\hline
\end{tabular}

* CIMTs are compared using one-way analysis of variance (ANOVA);

** Adjusted CIMTs are compared using analysis of covariance (ANCOVA) with adjustment for age, gender, household income, education level, current smoking status and drinking status, body mass index, hypertension, hyperglycemia, and dyslipidemia.

Table 3

Association of fruit and vegetable consumption with carotid plaque (CP) among 11,392 participants in this study.

\begin{tabular}{lccc}
\hline & $\begin{array}{c}\text { Participants with CP(s) } \\
\%(\mathbf{n} / \mathbf{N})\end{array}$ & $\begin{array}{c}\text { Logistic regression models } \\
\text { Model 1 * } \\
\text { OR }(\mathbf{9 5 \%} \% \mathbf{C l})\end{array}$ & $\begin{array}{c}\text { Model 2 ** } \\
\text { OR (95\%Cl) }\end{array}$ \\
\hline $\begin{array}{l}\text { Fresh vegetables } \\
\text { Rarely consumed }\end{array}$ & $44.7(491 / 1,098)$ & & \\
Occasionally consumed & $35.3(876 / 2,484)$ & $0.67(0.58-0.78)$ & 1.00 \\
$\quad$ Daily consumed & $36.1(2,819 / 7,810)$ & $0.70(0.62-0.79)$ & $0.63(0.54-0.74)$ \\
Fresh fruits & & & $0.67(0.58-0.77)$ \\
Rarely consumed & $40.8(1,598 / 3,915)$ & 1.00 & 1.00 \\
Occasionally consumed & $34.9(1,868 / 5,357)$ & $0.78(0.71-0.85)$ & $0.87(0.79-0.95)$ \\
Daily consumed & $34.0(720 / 2,120)$ & $0.75(0.67-0.83)$ & $0.95(0.84-1.07)$ \\
\hline
\end{tabular}

95\% Cl: 95\% confidence interval; OR: odds ratio.

* Model 1 is the unadjusted regression model;

** Model 2 is a multivariable regression model with adjustment for age, gender, household income, education level, current smoking status and drinking status, body mass index, hypertension, hyperglycemia, and dyslipidemia. 
Association of vegetable and fruit consumption with single carotid plaque (CP) among 9,859 participants in this study.

\begin{tabular}{|c|c|c|c|}
\hline & \multirow{3}{*}{$\begin{array}{c}\text { Participants with single } \\
\text { CP } \\
\%(n / N)\end{array}$} & \multicolumn{2}{|c|}{ Logistic regression models } \\
\hline & & Model 1 * & Model 2 ** \\
\hline & & OR $(95 \% \mathrm{CI})$ & OR $(95 \% \mathrm{CI})$ \\
\hline \multicolumn{4}{|l|}{ Fresh vegetables } \\
\hline Rarely consumed & $30.2(263 / 870)$ & 1.00 & 1.00 \\
\hline Occasionally consumed & $26.1(568 / 2,176)$ & $0.82(0.69-0.97)$ & $0.77(0.64-0.92)$ \\
\hline Daily consumed & $26.7(1,822 / 6,813)$ & $0.84(0.72-0.98)$ & $0.80(0.68-0.94)$ \\
\hline \multicolumn{4}{|l|}{ Fresh fruits } \\
\hline Rarely consumed & $29.3(958 / 3,275)$ & 1.00 & 1.00 \\
\hline Occasionally consumed & $26.0(1,229 / 4,718)$ & $0.85(0.77-0.94)$ & $0.93(0.84-1.03)$ \\
\hline Daily consumed & $25.0(466 / 1,866)$ & $0.81(0.71-0.92)$ & $0.98(0.86-1.12)$ \\
\hline
\end{tabular}

95\% Cl: 95\% confidence interval; OR: odds ratio.

* Model 1 is the unadjusted regression model;

** Model 2 is a multivariable regression model with adjustment for age, gender, household income, education level, current smoking status and drinking status, body mass index, hypertension, hyperglycemia, and dyslipidemia.

\section{Discussion}

In this large-scale population-based study, we aimed to explore the relationship between vegetable and fruit consumption and carotid atherosclerosis among adults at high CVD risk in China. We found that vegetable consumption was negatively associated with the risk of experiencing carotid plaque, a predictor of carotid atherosclerosis among residents at high CVD risk in regional China. Our findings were in line with that reported from previous original and meta-analyses studies 10,11,12.

A meta-analysis on prospective cohort studies showed that an additional intake of $300 \mathrm{~g}$ per day of fruit or $400 \mathrm{~g}$ per day of vegetables could reduce the risk of coronary heart disease by $16 \%$ and $18 \%$, respectively 11 . However, such a significant eating-behavior modification would not be viable for people. The nurses cohort from the United States reported a negative association between vegetables consumption and the risk of stroke but no link between fruit intake and stroke 24 . An ecological study on nine regions of Great Britain and 30 countries also reported that consumption of fresh green vegetables, not fruit, might reduce the risk of coronary heart diseases 25 .

There are several possible mechanisms that may explain the inverse association between fresh vegetable and fruit intake and CP. Vegetables and fruits contain many specific constituents, such as phytochemicals like flavonoids and antioxidant vitamins like $\mathrm{C}$ and $\mathrm{E}$, which contribute to vascular health 26. For instance, LDL oxidation has been suggested as the atherogenic factor contributing to CVD 27. Dietary antioxidants or phytochemicals scavenge free radicals to prevent LDL oxidation and prevent or delay the progression of atherosclerotic lesions 28 . Low intake of fruit was associated with other unhealthy behaviors like cigarette smoking and alcohol drinking 29 , which might increase the risk of developing CP 30,31.

Our study showed that the protective effect of fruit intake on single-plaque was not significant. One possible reason is that more than a quarter of the high CVD risk population experiencing hyperglycemia, which is strongly associated with carotid atherosclerosis. Frequent fruit intake may lead to high fructose intake, which may worsen glycemic control among diabetic patients 32 . Blood glucose, lipids, and blood pressure play important roles in the development and progression of type 2 diabetes mellitus with CP. Insulin resistance in diabetic patients can result in the release of large amounts of fatty acids from non-fatty tissues and a decrease in lipoprotein lipase activity, causing disturbances in lipid metabolism, thus leading to macrovascular disease and CP formation in the long term. Furthermore, a great difference was shown in the dietary pattern among Western populations and Asian populations. In China, although fresh vegetable consumption is more frequent, fresh fruit consump- 
tion is much less common than that in Western societies 33. Additionally, several studies also indicated that there exists publication bias in the field of association between fruit intake and CVD 11,34.

Our study also found no association between consumption of fresh vegetable and fruit and CIMT, which is consistent with that reported from a cross-sectional study and an experimental study 35,36 . The role of CIMT as a marker of atherosclerosis was controversial, especially when measured with CCA only 37. It was indicated that CIMT and plaque may reflect different biological aspects of atherogenesis and predict different clinical vascular diseases, although they are correlated 37 . Plaque is a stronger predictor for myocardial infarction, whereas CIMT is stronger related to hypertension and ischemic stroke 37.

There were some strengths of this study. Firstly, this is the first study that examined the association between vegetable and fruit consumption and carotid atherosclerosis in Chinese people at high risk of developing cardiovascular diseases. Secondly, with the multi-stage sampling method employed, we recruited a large-scale sample of participants with representativeness of the general population. Thirdly, classical potential confounders were considered in the analysis 38 .

Our study has several limitations. First, we did not collect information on amount (portion size) of vegetable and fruit consumed, as the simplified FFQ was applied in this study. Thus, the doseresponse relationship between vegetable and fruit intake and CP could not be examined 39,40. Second, the FFQ used to measure dietary intake was not specifically validated for our study, which might cause potential bias regarding information on vegetable and fruit consumption. However, it has been applied in the China Kadoorie Biobank (CKB) study and showed good acceptability 20. Third, given the characteristics of a cross-sectional study, our study cannot imply any causality between vegetable and fruit intake and carotid atherosclerosis. Fourth, the proportion of young residents was higher in those excluded (24.2\%) than that in their counterparts included (15.3\%), which might imply potential selection bias. Thus, this data point suggests that one should be prudent when explaining the findings examined in this study. Fifth, due to lack of detailed data on hypertension as well as diabetes/hyperglycemia and dyslipidemia, we could differentiate already-diagnosed and newly-diagnosed cases in the analysis, which might lead to potential classification bias, as people with already-diagnosed disease might modify their eating behaviors. In future, well-designed longitudinal studies are expected to investigate the association of vegetable and fruit consumption with CP in Chinese population.

\section{Conclusions}

Among people at high CVD risk in China, vegetable and fruit intake was inversely associated with experiencing carotid plaque, but no significant association between fruit and single plaque. Moreover, these associations were independent of lifestyle and atherosclerotic-related risk factors. It has public health implications that vegetable and fruit consumption interventions should be tailored for people at high risk in population-based campaigns against CVD in China. 


\section{Contributors}

F. Zhu coordinated and designed the study, analyzed the data, and prepared the first draft of the article. Y. Qin and J. Zhou coordinated and designed the study, organized the fieldwork and data collection, and substantively revised the draft. Y. Bi preprocessed the data and revised the draft. J. Su, L. Cui, P. Luo, W. Du, and W. Miao organized the fieldwork and data collection and revised the draft. J. Wang coordinated and designed the study and substantively revised the draft.

\section{Additional informations}

ORCID: Fangyu Zhu (0000-0001-8636-163X); Yu Qin (0000-0002-8973-8540); Yuan Bi (0000-00016444-3749); Jian Su (0000-0002-4026-4823); Lan Cui (0000-0002-7639-7476); Pengfei Luo (00000002-3358-1070); Wencong Du (0000-0001-54731165); Weigang Miao (0000-0001-7464-6566); Jinsong Wang (0000-0002-2526-6193); Jinyi Zhou (0000-0001-6057-862X)

\section{References}

1. He J, Gu D, Wu X, Reynolds K, Duan X, Yao $\mathrm{C}$, et al. Major causes of death among men and women in China. New Engl J Med 2005; 353:1124-34.

2. GBD 2013 Mortality and Causes of Death Collaborators. Global, regional, and national age-sex specific all-cause and cause-specific mortality for 240 causes of death, 1990-2013: a systematic analysis for the Global Burden of Disease Study 2013. Lancet 2015; 385:117-71.

3. Yusuf S, Hawken S, Ounpuu S, Dans T, Avezum A, Lanas F, et al. Effect of potentially modifiable risk factors associated with myocardial infarction in 52 countries (the INTERHEART study): case-control study. Lancet 2004; 364:937-52.

4. Yach D, Hawkes C, Gould CL, Hofman KJ. The global burden of chronic diseases: overcoming impediments to prevention and control. JAMA 2004; 291:2616-22.

5. Stewart J, Manmathan G, Wilkinson P. Primary prevention of cardiovascular disease: a review of contemporary guidance and literature. JRSM Cardiovasc Dis 2017; 6:2048004016687211

6. Stary HC, Chandler AB, Dinsmore RE, Fuster V, Glagov S, Insull Jr. W, et al. A definition of advanced types of atherosclerotic lesions and a histological classification of atherosclerosis. A report from the Committee on Vascular Lesions of the Council on Arteriosclerosis, American Heart Association. Circulation 1995; 92:1355-74.

\section{Acknowledgments}

We thank all the staff from Changzhou City, Huai'an City, Jiawang District, Changshu County, Hai'an County and Donghai County for their work and support on providing the data for this study. Fund programs: National Major Public Health Service Project, P.R. China (2014); Cadre Health Care Research Project of Jiangsu (BJ17011).

7. Polak JF, O'Leary DH. Carotid intima-media thickness as surrogate for and predictor of CVD. Glob Heart 2016; 11:295-312.e3.

8. Mozaffarian D, Appel LJ, Van Horn L. Components of a cardioprotective diet: new insights. Circulation 2011; 123:2870-91.

9. Van Duyn MA, Pivonka E. Overview of the health benefits of fruit and vegetable consumption for the dietetics professional: selected literature. J Am Diet Assoc 2000; 100:151121.

10. Dauchet L, Amouyel P, Hercberg S, Dallongeville J. Fruit and vegetable consumption and risk of coronary heart disease: a meta-analysis of cohort studies. J Nutr 2006; 136:2588-93.

11. Gan Y, Tong X, Li L, Cao S, Yin X, Gao C, et al. Consumption of fruit and vegetable and risk of coronary heart disease: a meta-analysis of prospective cohort studies. Int J Cardiol 2015; 183:129-37.

12. Ness AR, Powles JW. Fruit and vegetables, and cardiovascular disease: a review. Int J Epidemiol 1997; 26:1-13.

13. Oude Griep LM, Verschuren WMM, Kromhout D, Ocké MC, Geleijnse JM. Raw and processed fruit and vegetable consumption and 10-year stroke incidence in a populationbased cohort study in the Netherlands. Eur J Clin Nutr 2011; 65:791-9.

14. Lu J, Xuan S, Downing NS, Wu C, Li L, Krumholz HM, et al. Protocol for the China PEACE (Patient-centered Evaluative Assessment of Cardiac Events) Million Persons Project pilot. BMJ Open 2016; 6:e010200. 
15. World Health Organization. Prevention of cardiovascular disease: guidelines for assessment and management of total cardiovascular risk. Geneva: World Health Organization; 2009.

16. Bian L, Xia L, Wang Y, Jiang J, Zhang Y, Li D, et al. Risk factors of subclinical atherosclerosis and plaque burden in high risk individuals: results from a community-based study. Front Physiol 2018; 9:739.

17. Naqvi TZ, Lee MS. Carotid intima-media thickness and plaque in cardiovascular risk assessment. JACC Cardiovasc Imaging 2014; 7:1025-38.

18. Cao JJ, Arnold AM, Manolio TA, Polak JF, Psaty BM, Hirsch $\mathrm{CH}$, et al. Association of carotid artery intima-media thickness, plaques, and C-reactive protein with future cardiovascular disease and all-cause mortality: the Cardiovascular Health Study. Circulation 2007;116:32-8.

19. Onut R, Balanescu AP, Constantinescu D, Calmac L, Marinescu M, Dorobantu PM. Imaging atherosclerosis by carotid intima-media thickness in vivo: how to, where and in whom? Maedica (Buchar) 2012; 7:153-62.

20. Yu C, Shi Z, Lv J, Guo Y, Bian Z, Du H, et al. Dietary patterns and insomnia symptoms in Chinese adults: The China Kadoorie Biobank. Nutrients 2017; 9:232.

21. Chobanian AV, Alderman MH, DeQuattro V, Frohlich ED, Gifford RW, Hill MN, et al. The 1988 report of the Joint National Committee on Detection, Evaluation, and Treatment of High Blood Pressure. Arch Intern Med 1988; 148:1023-38.

22. World Health Organization. Definition and diagnosis of diabetes mellitus and intermediate hyperglycaemia: report of a WHO/IDF consultation. Geneva: World Health Organization; 2006.

23. Zhu JR, Gao RL, Zhao SP, Lu GP, Zhao D, Li JJ. 2016 Chinese guidelines for the management of dyslipidemia in adults. J Geriatr Cardiol 2018; 15:1-29.

24. Manson JE, Willett WC, Stampfer MJ, Colditz GA, Speizer FE, Hennekens CH. Vegetable and fruit consumption and incidence of stroke in women. Circulation 1994; 89:932.

25. Armstrong BK, Mann JI, Adelstein AM, Eskin F. Commodity consumption and ischemic heart disease mortality, with special reference to dietary practices. J Chronic Dis 1975; 28:455-69.

26. Liu RH. Health-promoting components of fruits and vegetables in the diet. Adv Nutr 2013; 4:384S-92S.

27. Witztum JL, Berliner JA. Oxidized phospholipids and isoprostanes in atherosclerosis. Curr Opin Lipidol 1998; 9:441-8.

28. Sánchez-Moreno C, Jimenez-Escrig A, SauraCalixto F. Study of low-density lipoprotein oxidizability indexes to measure the antioxidant activity of dietary polyphenols. Nutr Res 2000; 20:941-53.
29. Serdula MK, Byers T, Mokdad AH, Simoes E, Mendlein JM, Coates RJ. The association between fruit and vegetable intake and chronic disease risk factors. Epidemiology 1996; 7:161-5.

30. McEvoy JW, Nasir K, DeFilippis AP, Lima JA, Bluemke DA, Hundley WG, et al. Relationship of cigarette smoking with inflammation and subclinical vascular disease: the Multi-Ethnic Study of Atherosclerosis. Arterioscler Thromb Vasc Biol 2015; 35:1002-10.

31. Britton AR, Grobbee DE, den Ruijter HM, Anderson TJ, Desvarieux M, Engstrom G, et al. Alcohol consumption and common carotid intima-media thickness: The USE-IMT Study. Alcohol Alcohol 2017; 52:483-6.

32. Segal MS, Gollub E, Johnson RJ. Is the fructose index more relevant with regards to cardiovascular disease than the glycemic index? Eur J Nutr 2007; 46:406-17.

33. Micha R, Khatibzadeh S, Shi P, Andrews KG, Engell RE, Mozaffarian DJB. Global, regional and national consumption of major food groups in 1990 and 2010: a systematic analysis including 266 country-specific nutrition surveys worldwide. BMJ Open 2015; 5:e008705.

34. Dauchet L, Amouyel P, Hercberg S, Dallongeville J. Fruit and vegetable consumption and risk of coronary heart disease: a meta-analysis of cohort studies. J Nutr 2006; 136:2588-93.

35. Buil-Cosiales $P$, Irimia P, Ros E, Riverol M, Gilabert R, Martinez-Vila E, et al. Dietary fibre intake is inversely associated with carotid intima-media thickness: a cross-sectional assessment in the PREDIMED study. Eur J Clin Nutr 2009; 63:1213-9.

36. Sayegh M, Tsiountsioura M, Ray S. Can a fruit and vegetable derived supplement, rich in vitamin-C, modulate cIMT and FMD measurements in overweight and obese individuals over 12 weeks? FASEB J 2016; 30:lb369.

37. Johnsen SH, Mathiesen EB. Carotid plaque compared with intima-media thickness as a predictor of coronary and cerebrovascular disease. Curr Cardiol Rep 2009; 11:21-7.

38. Rosengren A, Subramanian SV, Islam S, Chow CK, Avezum A, Kazmi K, et al. Education and risk for acute myocardial infarction in 52 high, middle and low-income countries: INTERHEART case-control study. Heart 2009; 95:2014-22.

39. Arai Y, Watanabe S, Kimira M, Shimoi K, Mochizuki R, Kinae N. Dietary intakes of flavonols, flavones and isoflavones by Japanese women and the inverse correlation between quercetin intake and plasma LDL cholesterol concentration. J Nutr 2000; 130:2243-50.

40. Tarrazo-Antelo AM, Ruano-Ravina A, Abal Arca J, Barros-Dios JM. Fruit and vegetable consumption and lung cancer risk: a case-control study in Galicia, Spain. Nutr Cancer 2014; 66:1030-7. 


\section{Resumo}

$O$ estudo buscou investigar a associação entre consumo de frutas e verduras e placa carotídea (PC) e espessura intima-média carotídea (EIMC), dois preditores de aterosclerose entre adultos das áreas urbana e rural com alto risco de desenvolver doenças cardiovasculares (DCVs) em uma região da China. Foram identificados 11.392 adultos com alto risco de DCV, entre 71.511 indivíduos da população geral, em um estudo transversal entre novembro de 2015 e maio de 2016 na Província de Jiangsu. Entre esses 11.392 participantes de alto risco, a prevalência de PC foi de 36,7\%. As variáveis independentes, ou seja, frequências de consumo de frutas e verduras, foram avaliadas através de um questionário de frequência alimentar. As variáveis de desfecho, EIMC e PC, foram medidas por ultrassom. A análise ANCOVA não mostrou associação entre valores de EIMC e frequências de consumo de frutas e verduras. Foram introduzidos modelos de regressão logística multivariada para examinar a associação entre consumo de frutas e verduras e PC. Depois de ajustar para potenciais fatores de confusão, as ORs para participantes com consumo eventual e diário de verduras para qualquer PC foram 0,67 (IC95\%: 0,58-0,78) e 0,70 (IC95\%: 0,62-0,79), respectivamente, comparado com aqueles com consumo raro de verduras. Enquanto isso, as ORs ajustados foram 0,77 (IC95\%: 0,64-0,92) e 0,80 (IC95\%: 0,68-0,94), separadamente, para adultos com consumo eventual e diário de verduras para desenvolver uma PC única, comparado aos que relatavam consumo raro de verduras. Entretanto, não foi observada uma associação significativa entre consumo de frutas e PC. Entre a população chinesa com alto risco de DCV, o consumo de verduras frescas mostrou associação negativa com o risco de desenvolvimento de placa carotídea.

Doenças Cardiovasculares; Aterosclerose;

Espessura Intima-Media Carotídea;

Estenose das Carótidas

\section{Resumen}

El objetivo de este estudio fue investigar la asociación del consumo de frutas y verduras con la placa carotídea (PC) y el grosor intima-media carotídeo (GIMC), dos predictores de la aterosclerosis carotídea en adultos urbanos y rurales, con alto riesgo de desarrollar enfermedades cardiovasculares $(E C V)$ en una región de China. Se identificaron, en este estudio transversal, a 11.392 adultos con alto riesgo de ECV dentro de una población general de 71.511, realizado entre noviembre de $2015 y$ mayo de 2016 en la provincia de Jiangsu. De estos 11.392 participantes en alto riesgo, la prevalencia de PC fue de un 36,7\%. Las variables independientes, así como la frecuencia de consumo de verduras y fruta, se evaluaron mediante un cuestionario de frecuencia de comidas. Las variables de resultado, GIMC y PC, se midieron por un examen de ultrasonido. El análisis ANCOVA mostró que no existía asociación entre los valores GIMC y la frecuencia en el consumo de verduras y frutas. Los modelos de regresión logística multivariantes se introdujeron para examinar la asociación entre el consumo de verduras y frutas y la PC. Tras el ajuste para los factores potenciales de confusión, las ORs de haber tenido alguna PC para los participantes que ocasionalmente $y$ diariamente consumian verduras fueron 0,67 (IC95\%: 0,58-0,78) y 0,70 (IC95\%: 0,62-0,79), respectivamente, comparadas con quienes raramente consumian verduras. Mientras que las ORs ajustadas fueron 0,77 (IC95\%: 0,640,92) y 0,80 (IC95\%: 0,68-0,94), separadamente, para los consumidores ocasionales y los consumidores diarios de verduras de desarrollar una única $P C$, en relación con sus contrapartes que raramente consumian verduras. No obstante, no se observó una asociación significativa entre el consumo de frutas y la PC. Entre la población con alto riesgo de ECV, el consumo de verdura fresca estuvo negativamente asociado con el riesgo de desarrollar PC.

Enfermedades Cardiovasculares; Aterosclerosis; Grosor Intima-Media Carotídeo; Estenosis Carotídea
Submitted on $21 / \mathrm{Feb} / 2020$

Final version resubmitted on 13/Aug/2020

Approved on 04/Sep/2020 